\title{
Para Fundir Arte \\ e Vida, o Teatro de Rua \\ Contemporâneo
}

To Merge Art and Life, The Contemporary Street Theater

Altemar Gomes Monteiro ${ }^{1}$

\section{RESUMO}

O presente artigo, inserido nos estudos aplicados aos processos criativos do Teatro Contemporâneo, lança-se ao desafio de refletir sobre a noção de Teatro de Rua Contemporâneo, a partir da experiência do Nóis de Teatro (Fortaleza - CE). A partir da experiência do grupo teatral na periferia urbana, seja nos processos de montagem ou na própria lógica de encenação/dramaturgia proposta ao espectador, o artigo se pergunta sobre as possibilidades dessa cena teatral que se faz atravessar pelos tempos e pelas materialidades discursivas, arquitetônicas, simbólicas e políticas da cidade. A proposição do trabalho é, expandindo o campo de ação das Artes Cênicas, estimular o diálogo com urbanismo, refletindo sobre o que o teatro reconfigura, a partir do sensível como fusão da arte e da vida, sobre a própria experiência de cidade.

Palavras-Chave: Teatro de Rua Contemporâneo. Nóis de Teatro. Cidade. Periferia.
Doutorando em Artes da Cena pela Universidade Federal de Minas Gerais. ORCID: http://orcid.

org/oooo-0002-1633-3235 Contato:

altemargm@yahoo.com.br 


\section{ABSTRACT}

This article, inserted in the studies applied to the creative processes of the Contemporary Theater, throws itself at the challenge of reflecting on the notion of Contemporary Street Theater, based on the experience of Nóis de Teatro (Fortaleza-CE). From the experience of the theatrical group in the urban periphery, whether in the assembly process or in the enacting / dramaturgy logic proposed to the spectator, the article asks about the possibilities of this theatrical scene that is crossed by the times and the discursive materialities, Architectural, symbolic and political of the city. The proposition of the work is to expand the field of action of the Scenic Arts, to stimulate the dialogue with urbanism, reflecting on what the theater reconfigures, from the sensitive as a fusion of art and life, about the city experience itself.

Keywords: Street theater. Nóis de Teatro. City. Periphery. 
Pensar o espaço, o local dos espetáculos e, associado a isto, pensar a dramaturgia, o ator e as suas relações com o espectador, é também pensar o mundo. o grande espetáculo do mundo não cabe no espaço reservado para o espetáculo do grupo social que se julgar dono do mundo HADDAD, 2008, p. 149

É preenchido pelo desejo inquietante de pensar num teatro que se pauta a partir do seu contato direto com o espaço urbano e a materialidade poética da cidade que o presente artigo desenha suas reflexões, empreendidas a partir da experiência de Teatro de Rua do Nóis de Teatro ${ }^{2}$ em seu contato com o espaço público periférico e os habitantes de Fortaleza, no estado do Ceará. Assim, inserida nos estudos contemporâneos que aspiram a um campo expandido para as artes cênicas, a pesquisa que tenho realizado nos últimos anos tem atuado na análise das relações de artistas de teatro com o espaço urbano, tendo a cena como espaço de produção de pensamento, intervenção poética e política na cidade. É renovando o campo de ação do próprio teatro, tendo-o como um amálgama de inter-relações com tempos, espaços, contextos e subjetividades, que tal estudo borra as fronteiras das artes e do urbanismo, refletindo sobre teatro de rua na contemporaneidade, e fazendo interfaces diretas entre teatro e cidade, seja nos aspectos de dramaturgia ou de encenação.

A partir de uma prática que se enraíza em 15 anos de teatro, o presente artigo traz algumas reflexões a partir da experiência do Nóis de Teatro, grupo de Fortaleza - CE, que participo desde a sua fundação, dando-nos margem para refletir de modo profundo sobre os percursos e percalços que tecem esse teatro produzido nas ruas da cidade. Tais reflexões nos indicam, no campo da pesquisa aqui avistada, um universo amplo de pressupostos e marcos conceituais que elucidam as práticas de teatro de rua na contemporaneidade, dando-nos margem para compreender em que contexto poético, político e social o trabalho do Nóis de Teatro tem se inserido. Ainda assim, será importante reconhecermos que, mesmo calçados com os pressupostos conceituais e teóricos que aqui se evidenciam, é nos processos criativos, sempre únicos e efêmeros, que o pensamento se complexifica.

Nesse lugar de pensamento, tendo a rua como vertigem poética, interessa-me a pulsão de um contingente de expressões que fundem o que é arte ao que é público, entendendo este último para além da noção de "plateia", mas que, em sua premência, incorpora uma troca sinérgica existente numa força comunitária que se faz em diálogo, construção pública e política. Para começo das
2.

Coletivo do qual participo, desde a sua fundação, como encenador teatral, assumindo, ao longo da história do grupo, a direção de diversas montagens, experimentos e estudos cênicos junto a outros oito artistas também moradores da periferia de Fortaleza. Nossa produção poética, desde o começo, forja-se a partir da nossa relação com o bairro onde moramos. Para isso, o espaço público - para além da roda tradicional de teatro de rua que ele possibilita passa a ser, para o Nóis de Teatro, ambiente catalisador de um olhar que agencia criatividades exemplificadas numa série de ações e atos performáticos que realizamos entre poças de lama e becos da periferia de Fortaleza ao longo desses anos. 
reflexões aqui empreendidas, interessa o que Amir Haddad, diretor do Grupo Tá na Rua (RJ), reflete ao dizer-nos que, com o advento da burguesia e o desenvolvimento do modo capitalista protestante de produção, o teatro foi perdendo suas características de festa e celebração populares, e passou "pouco a pouco a se transformar num produto especial, a ser consumido por um grupo social homogêneo que se apodera desta forma de manifestação popular e a submete às nascentes regras do mercado" (HADDAD, 2008, p. 153). Para compreendermos o fenômeno poético e político intrínseco a este lugar é necessário não arrefecer ao reconhecermos as investidas estratégicas das sociedades burguesas para estruturar um sistema-mundo que separa arte e vida, agindo na segregação entre artista e público. Assim, o complexo movimento de teatro de rua que tem eclodido nos últimos anos no Brasil parece reacender um movimento politemporal ${ }^{3}$ anterior a esse advento burguês, período em que os espaços públicos eram utilizados para manifestações artísticas, tempo-espaço anterior à edificação dos grandes teatros ${ }^{4}$ e espetáculos realizados de acordo com os interesses econômicos da classe dominante. Se hoje é possível ver, vez ou outra, Praças e Ruas ocupadas com manifestações populares, teatro e dança de rua, além de outras expressões artísticas, é exatamente pelo que se deseja enquanto lugar de partilha e sociabilidade, além de experimentação estética e política do uso social de um lugar. Amir Haddad (2008, p. 146) fala que

\begin{abstract}
hoje, se o teatro quiser recuperar a sua força comunitária, deverá romper com os 300 anos de isolacionismo e ilusionismo em que os valores, a ética, a estética e a moral burguesa o envolveram, e buscar novas maneiras de se relacionar com seu público, sob pena de ficar cada vez mais hermético e fechado sobre si mesmo, e cada vez mais distanciado de sua plateia, que nele não se reconhece e através dele não cresce; o que faz como espetáculo passa a ser mais do que um aparato visual para a contemplação de uma plateia passiva e desinteressada.
\end{abstract}

Defendendo enquanto modelo poético a necessidade de um teatro que se faça em espaços abertos e comunitários5, Haddad cita o teatro brechtiano, as peças de Maiakovski ou de García Lorca, ou ainda a força popular dos atores da Commédia dell'Arte, como uma teatralidade que se faz para um público heterogêneo, negando, desde então, a homogeneidade das plateias e dos espaços.

Em sequência, no século XIX algumas resistências já pulsavam enquanto possibilidade na arte, envolvendo artistas que já previam a necessidade de romper fronteiras historicamente
3.

O filósofo Bruno Latour apresenta o termo politemporal para falar-nos de um tempo que não é visto como um panorama geral, mas como resultado provisório da ligação entre os seres. O autor fala de tempos que são agrupados a partir de uma espiral e não mais de uma linha. Desse modo, "certamente temos um futuro e um passado, mas o futuro se parece com um círculo em expansão em todas as direções, e o passado não se encontra ultrapassado, mas retomado, repetido, envolvido, protegido, recombinado, reinterpretado e refeito (...) Tal temporalidade não força o uso dos rótulos 'arcaicos' ou 'avançados', já que todo agrupamento de elementos contemporâneos pode juntar elementos pertencentes a todos os tempos" (LATOUR, 2013, p. 74).

4.

Amir Haddad, no texto "Espaço e ideologia", fala que o teatro grego, com seu anfiteatro e o espaço para a atuação do coro, confirma a importância comunitária desta forma de expressão para os gregos. "Depois o teatro desaparece enquanto edifício, durante uma dezena aproximada de séculos, e mantém-se vivo apenas pela atividade isolada dos atores, que caminhando sós pelas estradas da época se exibiam para um mundo atomizado e dividido" (HADDAD, 2008, p. 152).

5.

Colaborando com este pensamento, Hélio Oiticica, ao falar dos seus 'parangolés', defendia uma verdadeira retomada "dessa estrutura mítica primordial da arte, que sempre existiu, é claro, mas com maior ou menor definição. Da arte renascentista em diante houve como que um obscurecimento desse fator que tendeu, com o aparecimento da arte do nosso século, a emergir cada vez mais" (OITICICA, 1986, p. 68). Mais adiante serão consideradas, de maneira mais detalhada, as ideias de Oiticica. 
semeadas e reiteradas, para a configuração de outras possibilidades na fricção arte e vida. É nessa instância que faz-se necessário concordar com Baudelaire (2010, p. 39) que, nessa época, já estava interessado na dessacralização da arte. Ao ser presenteado com os encontrões das multidões da nova modernidade, o poeta derruba o halo da sua cabeça e lança-o no lodo do macadame, apresentando a possibilidade de um artista que esteja muito mais próximo do homem $^{6}$ do que do divino, descobrindo, para seu espanto, "que a aura de pureza e santidade artística é apenas incidental e não essencial à arte e que a poesia pode florescer perfeitamente, talvez melhor ainda, no outro lado do bulevar, naqueles lugares baixos, 'apoéticos', como o 'mauvais lieu' onde esse mesmo poeta nasceu” (BERMAN, 1986 , p. 155, grifos do autor). Na sua reivindicação de uma arte que rompa com os padrões esteticistas de sua época, Baudelaire percebe nos lugares "apoéticos" da cidade, um ambiente criativo e eminentemente paradoxal que desestabiliza um mundo pretensamente asséptico e que busca obliterar tudo o que perturba a sua harmonia.

Algo parecido com o que o artista visual Hélio Oiticica (19371980) realiza ao dizer que "o museu é o mundo", trazendo consigo nesse aforismo uma perspectiva revolucionária de entendimento da vida cotidiana enquanto dispositivo poético. Oiticica amplia o seu olhar sobre o mundo que lhe cerca, entendendo-se como parte integrante dele, implicado na sua construção, contribuindo para diminuir as barreiras que separam arte e vida. Hélio Oiticica (HO), assim como outros artistas plásticos e visuais de sua época, falavam de antiarte com o intuito de desmistificar a obra e contribuir para uma vivência coparticipativa junto ao espectador, reação muito clara à arte modernista de sua época. Oiticica falava que

A antiarte é pois uma nova etapa (é o que Mário Pedrosa sabiamente formulou como arte pós-moderna); é o otimismo, é a criação de uma nova vitalidade na experiência humana criativa; o seu objetivo é o de dar ao público a chance de deixar de ser público espectador, de fora, para participante na atividade criadora" (OITICICA, 1986, p. 82).

Nesse contexto, o mundo - a cidade, a praça -, passa, então, a ser o quadro do pintor, o instrumento do músico e, no nosso caso, o espaço de atuação do ator e habitat do diretor que sai do seu isolamento intuitivo para perceber que nas relações cotidianas da cidade surge um outro poético emergente de ser visto, vivido e experienciado pela comunidade que o constrói. É nesse contexto que, assim como Amir Haddad ou o Nóis de Teatro, um grande contingente de outros artistas e grupos tem se interes-
6.

Baudelaire, apresentando a obra de Constantin Guys, reivindica uma ruptura com o esteticismo reinante no século XIX para a configuração de uma arte mais vinculada a tudo que se passa na superfície do nosso planeta. Argumenta que é necessário entender a obra de C.G. como a de um "homem do mundo inteiro, homem que compreende o mundo e as razões misteriosas e legítimas de todos os seus costumes", ao passo que o artista tem sido visto como especialista, "homem preso à paleta tal como servo à gleba, (...) sua conversa, forçosamente limitada a um círculo muito estreito, depressa se torna insuportável ao homem do mundo, ao cidadão espiritual do universo" (BAUDELAIRE, 2010, p 25-26). 
sado em pensar a urbe como potência criativa, a Praça como lugar não somente de sociabilidade, mas como sítio que agencia uma ludicidade criadora que não cansa de impelir o artista ao diálogo com suas estruturas topográficas, arquitetônicas, simbólicas, econômicas, geopolíticas e culturais.

Haddad fala que existe um teatro imanente na cidade, que "há uma possibilidade teatral imanente no cidadão e nos ritos de convivência, não prevista na vida da cidade e consequentemente não levada em conta" (HADDAD, 2008, p. 218). Quando Haddad se refere à imanência do teatro na cidade é possível dizer que ele esteja atuando bem próximo às ideias do filósofo Gilles Deleuze quando o mesmo fala que "a imanência absoluta existe em si-mesma: ela não existe em algo, ela não é imanência a algo, ela não depende de um objeto e 'não pertence a um sujeito'" (DELEUZE, 2002, p. 12, grifo meu) ${ }^{7}$. É nessa perspectiva que esse sentido imanente alia-se de forma veemente ao projeto baudelairiano de jogar o halo no lodo do macadame, apontando para um teatro sem proprietário, saindo dos seus prédios, da sua força de instituição de arte, o que leva Haddad a eliminar "a diferença entre cidadão e artista, e a criar um espaço onde é possível a cidadania se manifestar artisticamente" (HADDAD, 2008, p. 2019). "A imanência torna-se, desta maneira, um combate contra as formas de sociabilidade resultantes das filosofias e políticas que prescrevem um dever ser e que submetem o real a um julgamento extrínseco, transcendente, e, portanto, arbitrário" (MERÇON, 2010, p. 98).

Haddad revela, então, compreender a cidade como grande teatro poético que, em si, possui um arcabouço de significados a serem explorados, grafando os cidadãos como coprotagonistas dessa construção a partir do manuseio dos seus significados e do constante tráfego dessa nova urbanidade. Nesse sentido, ao falarmos desse 'desejo de rua', de envolvimento com o "tráfego", tratamos da compreensão desse teatro imanente na cidade, capaz de suscitar uma interlocução não somente com o espaço urbano arquitetônico, mas com o fluxo de seus habitantes, o que contribui para rever a segregação entre artista e cidadão e pulsar a necessidade de pensarmos, desde então, no que poderia ser defendido como um artista-cidadão ou mesmo um cidadão-artista.

A partir dessa compreensão, em referência a Oiticica, o artista cearense Enrico Rocha traz a noção tão pertinente de que "o mundo é a obra". Obra entendida não enquanto produto, mas como esse fazer constante da criação artística sobre o real, obra como processo, colocar a "mão na massa". Se o mundo é a obra, tudo passa então a ser arte.
7.

A filosofia deleuzeana ajuda-nos a compreender a ideia de plano de imanência nas sociedades pós-modernas. "Uma das implicações político-filosóficas que advêm da afirmação de uma imanência absoluta é a colocação do jogo da vida e de suas regras em um mesmo mundo, desprovendo de todo sentido a busca de um momento fundacional ou de um fim supremo (...). O desacordo e a disputa operam neste mundo, não remetem a causas, objetivos, explicações ou determinações que estejam em nenhum outro lugar. A imanência significa que a exterioridade deixou de estar além do mundo" (MERÇON, 2010, p. 98). Nesse sentido, sempre que falarmos de imanência nesta dissertação não trataremos de relações metafóricas e sim, a partir de Deleuze e Haddad, de um "plano real", de efeitos reais produzidos e inscritos na materialidade vivida, traduzidas em operações concretas de produção, e não de representação ou transcendência. 
A pessoa comum que passeia pelo centro da cidade, o surfista que pega onda no Titanzinho, o menino do Poço da Draga que pula da ponte velha, o leitor que acompanha esse texto, a dona de casa que prepara o almoço da família, o motorista que conduz o ônibus cheio de trabalhadores, o ciclista que enfrenta o transito caótico, todos nós, a todo instante, estamos realizando experiências estéticas (ROCHA, 2014).

Assim, presume-se que pensar o mundo enquanto obra, implica entender que este não está posto como tal, mas que é construído por uma série de intervenções que realizamos nele e junto à ele. Através dessa perspectiva, talvez já seja possível dizer que os processos criativos em arte não apenas criam obras, mas inventam o próprio sentido de mundo, reinventando também o cotidiano. Contudo, ao afirmar que tudo é arte, que consequências estamos dispostos a assumir com essa afirmação? Se tudo é arte, qual a necessidade de espaços sede de grupos teatrais, financiamento de montagens, prêmios de reconhecimento de mérito ou outros mecanismos de distinção do trabalho de artistas?

A partir destas questões, atentemos ao panorama apresentado a seguir, buscando agir de maneira distinta aos domínios que ele revela. Reconheçamos que, ao fundirmos arte e vida, poderemos cair também no risco de inserir nesse panorama os domínios capitalísticos ${ }^{8}$ sobre as formas de consumo e produção de subjetividade, o que significa dizer, na esteira de Marshall Berman, que o entretenimento especializado, a tecnologia industrial, a moda, o design, a política, passam também a reivindicar sua chancela e carimbo de arte. "À medida que a mídia e a cultura de massa foram ganhando poder, foram conquistando o espaço que antes era ocupado exclusivamente pela universidade e pela cultura erudita" (ROLNIK, 2014, p. 89). Com efeito, é interesse também dessa indústria cultural dessacralizar a arte, derrubando o seu halo e trazendo-a para a reprodução em série ${ }^{9}$. Foi nesse trajeto que surgiram a pop art e outras alternativas de mobilização de um conjunto de interesses da indústria cultural em paralelo a supostos processos de produção de sensibilidade. O problema estava, segundo Berman (1986, p. 31), "em que o modernismo pop nunca desenvolveu uma perspectiva crítica que pudesse esclarecer até que ponto devia caminhar essa abertura para o mundo moderno e até que ponto o artista moderno tem a obrigação de ver e denunciar os limites dos poderes deste mundo".

O desafio do artista instalado no meio do fogo cruzado desse embate estaria, desse modo, na capacidade de ir à contramão desses interesses e, numa perspectiva crítica, desvendar na vida cotidiana das cidades uma poética desviante, mobilizando o
8.

Guatarri e Rolnik apresentam, no texto "Cultura: um conceito reacionário?", o termo 'capitalístico' defendendo que "a própria essência do lucro capitalista não se reduz ao campo da mais-valia econômica: ela está também na tomada de poder da subjetividade" (GUATARRI, ROLNIK, 1986, p. 16).

9.

Para uma maior entrada nesse debate, ver o texto "A obra de arte na época da reprodutibilidade técnica", de Walter Benjamin. 
cidadão à transformação cotidiana das suas realidades como lugar de significado sensível. No caso do trabalho do Nóis de Teatro, é a constatação desse plano de imanência da cidade que tem nos feito sair dos domínios da nossa sede na periferia de Fortaleza para descortinar a poética instalada na urbanidade. Os atos performáticos vivenciados em grupo atuam, sobretudo, nesse campo misterioso da fronteira arte e vida, operando com materiais antes não avistados em nossas criações realizadas outrora. Na poética do Nóis de Teatro, essa perspectiva tem se complexificado ao adentrarmos com maior força à compreensão de nossa atuação como objeto desse mundo-obra, buscando nos abrir ao sensível inscrito na poética dos espaços e arquiteturas urbanas, já que "a cidade é por si só teatral, é dramática, e que o teatro está impregnado dessas possibilidades de expressão" (HADDAD, 2008, p. 218). A cena teatral do Nóis de Teatro é gestada na rua, a partir da rua, atravessada pela rua e, por que não dizer, produzindo rua. Não podemos negar o quanto os espaços por onde passamos foram atravessados e transformados pela nossa ação, produzindo o efeito de reflexo de, também, em contrapartida, metamorfosear a nós mesmos. Não num âmbito numerável, quantificável e de fácil apreensão, mas no território do sensível e do poético.

Esse desejo irrequieto de reparação da interseção arte e vida tem frutificado um celeiro de teorias contemporâneas que tem se preocupado em afirmar a ação direta da arte como acontecimento que interfere na vida e vice-versa, produzindo o que diversos teóricos vão chamar de "performatividade"10. Nesse sentido, no campo das artes cênicas, a teórica canadense Josette Féral vai dizer que no centro da obra performativa

a performance toma lugar no real e enfoca essa mesma realidade na qual se inscreve desconstruindo-a, jogando com os códigos e as capacidades do espectador (...). Essa desconstrução passa por um jogo com os signos que se tornam instáveis, fluidos, forçando o olhar do espectador a se adaptar incessantemente, a migrar de uma referência a outra, inscrevendo sempre a cena no lúdico (FÉRAL, 2008, p, 203).

Nesse sentido, reconhecendo a fronteira criativa do movimento realizado entre arte e vida, o Nóis de Teatro passa a reinventar seu espaço de atuação, reconhecendo a praça como lócus de criação poética que nos atravessa e, em contraponto, nossa ação como mola propulsora da criação de outras realidades. É nesse sentido que, nesta pesquisa, ao afirmar, junto à Josette Féral, um teatro performativo, trabalhamos nas fronteiras entre ficção e realidade, levando em consideração um ato performativo que se inscreve contra uma "teatralidade criadora de sistemas representativos"
10.

A teoria de Austin, muito utilizada como proveito no campo dos estudos da performance, faz um relevante estudo sobre a emissão e recepção dos discursos observando os fenômenos dos atos de fala como acontecimentos performativos que executam uma ação, que realizam algo, ao invés de somente dizer. Em sequência, Jacques Derrida, no texto "Assinatura Evento Contexto", mesmo tecendo uma crítica a Austin, incorpora a esta teoria a noção de sucesso e malogro, assinalando que "o performativo é uma 'comunicação' que não se limita essencialmente a transportar um conteúdo semântico já construído e vigiado por um objeto de verdade" (DERRIDA, 1991, p. 363 , grifo do autor). 
e insistindo "no aspecto lúdico do discurso sob suas múltiplas formas (visuais ou verbais: as do performer, do texto, das imagens ou das coisas)" (FÉRAL, 2008, p. 207). O teatro não passa inerte à rua, assim como a rua não paralisa ao movimento realizado pela arte, o que quer dizer que nesse plano de imanência, marcado pela sua materialidade e seu efeito de real, há um jogo potente de transformação e construção de outros mundos possíveis. Talvez estejamos ainda falando de um plano idealizado, sobretudo num tempo massificado pelo consumo, mas o que se pontua aqui, quando falo da fusão arte e vida, é que quando a cidade passar a compreender sua vida cotidiana como lugar de experiências sensíveis, a arte não desaparecerá, confundindo-se com as dinâmicas próprias da vida cidadã, mas, minimamente, talvez ela deixe de habitar aquele lugar aburguesado para ceder à potência do saber poético imanente na vida do cidadão. Este deixa de ser espectador passivo para ser coautor da experiência artística e da produção da cidade, ou no dizer de Ranciére, um espectador emancipado:

A lição emancipadora do artista, oposta termo a termo à lição embrutecedora do professor, é a de que cada um de nós é artista, na medida em que adota dois procedimentos: não se contentar em ser homem de um ofício, mas pretender fazer de todo trabalho um meio de expressão; não se contentar em sentir, mas buscar partilhá-lo (RANCIÉRE, 2002, p. 79).

Essa emergente restauração da partilha do artista com a cidade, do cidadão com a pólis, como dito outrora, pode ser vista como uma chave importante para compreendermos o Teatro de Rua Contemporâneo e, neste entremeio, o próprio trabalho realizado pelo Nóis de Teatro. Com efeito, o contato de intercâmbio ${ }^{11}$ realizado pelos artistas do Nóis de Teatro com o Tá na Rua, em março de 2011, foi de fundamental importância para repensarmos muito das nossas práticas e da relação com o espectador, revelando-nos uma imagem da cena na qual "tudo é público e nada é especializado. O cidadão e o artista são as mesmas pessoas e as representações teatrais se transformam em acontecimentos públicos" (HADDAD, 2008, p. 224). Tais perspectivas, vistas por Amir Haddad (2008, p. 225) como rebeldia, como "um abandono do regime vigente e busca de outras possibilidades, fora dos padrões tradicionais da sociedade burguesa, que é privatizadora e especializadora", buscam romper com a ideia de que "só poucos são artistas e os outros são espectadores; de uma divisão do mundo entre passivos e ativos", perspectiva que interfere de forma crítica no modo como a ideia de cultura vem sendo gerida pelos órgãos institucionalizados e oficiais.
11.

Em março de 2011, o Nóis de Teatro participou, junto ao Grupo Pavilhão da Magnólia, de uma ação de intercâmbio junto ao Grupo Tá na Rua, na sua sede, na Lapa - Rio de Janeiro. Nos encontros, pudemos perceber as ações do Tá na Rua no sentido de pensar um teatro a partir das manifestações carnavalescas de rua e do trabalho de improvisação do ator. Algum tempo antes, já tínhamos participado de uma oficina ministrada por Licko Turle em Fortaleza, o que nos impulsionou a buscar entender esse "teatro sem arquitetura, essa dramaturgia sem literatura, esse ator sem papel", preconizado pelo Tá na Rua. 
Guatarri e Rolnik (1986, p. 22) podem contribuir nesse debate sobre teatro ao nos apresentar a noção de cultura como um conceito reacionário. Os autores reivindicam o valor especializado da cultura em paralelo à compreensão das suas singularidades, contrapondo-se também à hegemonia dos discursos capitalísticos, perguntando-se:

\begin{abstract}
Como fazer com que essas categorias ditas "da cultura" possam ser, ao mesmo tempo, altamente especializadas, singularizadas (...), sem que haja por isso uma espécie de posse hegemônica pelas elites capitalísticas? Como fazer com que a música, a dança, a criação, todas as formas de sensibilidade, pertençam de pleno direito ao conjunto dos componentes sociais? Como proclamar um direito à singularidade no campo de todos esses níveis de produção, dita "cultural", sem que essa singularidade seja confinada [no sentido de uma classificação fechada e de tomada de posse exclusiva]?
\end{abstract}

Ao compreendermos as artes como domínio de conhecimento, como possível leitura, releitura e transformação do mundo-obra e construção de partilha de saberes, é possível notarmos que também este conhecimento, muitas vezes, opera estabelecendo limites de territórios. De tal modo, é relevante apontar o próprio edifício teatral como um lugar de tradição e especialidade, revestido de valores que a Cultura, sobretudo a ocidental, conferiu-lhe ao longo dos últimos séculos. Se analisarmos, por exemplo, a origem dos espectadores de teatro que frequentam o Centro Dragão do Mar de Arte e Cultura ou mesmo o SESC Iracema e a Caixa Cultural, todos no mesmo quadrilátero cultural em Fortaleza, é possível perceber uma certa concentração social, em sua maioria de intelectuais, artistas e estudantes de classe média e alta. Isso porque o prédio teatral talvez ainda esteja revestido de uma máscara de poder que afasta as populações que habitam as periferias da cidade, que ainda veem esses lugares como territórios de conhecimento e saber especializados, pertencentes a uma elite intelectual, bem distantes de suas realidades. É por esse ângulo que o crítico e dramaturgo francês Georges Banu fará o seu elogio aos lugares que não são tidos institucionalmente como teatrais. $O$ autor fala que esses outros espaços, ao invés da especialização, provocam-nos à recuperação e rememoração dos lugares, já que eles suscitam um sentimento agudo de verdade.

Como locação ou abrigo cuidadosamente pesquisado, ele acolhe um artista satisfazendo suas expectativas e aliviando seus temores em relação ao teatral. Ao falso. Por isso o público também descobre, a priori, um espaço que o torna confiante, favorecendo a reunião de seres que o frequentam (BANU apud CARDOSO, 2008, p. 216). 
Fazendo coro ao discurso do Amir Haddad, é possível afirmar que uma das rupturas do território de domínio desse poder místico sobre o prédio teatral pode ser encontrada na saída enérgica da sua arquitetura. Romper as fronteiras da especialidade talvez seja realmente um caminho plausível de construção poética ilimitada, sensível ao outro, tecendo devires e reconstruindo novos campos de ação e produção de saber. Vislumbrando a cidade como espaço poético, a rua como lócus da experiência teatral, podemos aproximar os praticantes ordinários da cidade, como nos fala Certeau, à compreensão da urbanidade como poética e lugar de criação. É exatamente aqui que, a partir da experiência do Nóis de Teatro, e entendendo essas tensões que concernem ao Teatro como um todo, que podemos começar a pensar o que detona poeticamente o Teatro de Rua Contemporânea.

Na experiência de 15 anos de teatro realizado na rua junto ao Nóis de Teatro, sobretudo no que se refere ao vivenciado no processo de "O Jardim das Flores de Plástico ${ }^{12 "}$ " é possível concordar com a fala de Banu em que, no corpo a corpo com o povo da rua, vamos tecendo um acontecimento poético único, partilhado em trocas mútuas junto ao espectador. No geral, nossos espetáculos, partindo de um sentimento de co-realização junto aos espectadores, são entretecidos pelo que a plateia aciona de saber, aglutinando à cena suas opiniões, reflexões e conclusões: uma via interativa que, na maioria das vezes, faz com que diversas cenas de nossas peças sigam a partir do que o espectador coloca e propõe ${ }^{13}$. Conhecimento que vai sendo tecido para além dos ditames de uma especialidade, mas que, envolvendo a participação plena de todos seus membros na construção colaborativa dos seus significados, gera uma cultura comum (diferente de uma cultura em comum), traçada coletivamente e que vai sendo "refeita e redefinida pela prática de seus membros, e não aquela na qual valores criados pelos poucos são depois assumidos e vividos passivamente pelos muitos" (EAGLETON, 2011, p. 169) ${ }^{14}$.

Pensando dessa forma, uma série de artistas de teatro tem trabalhado para a construção de uma poética de diálogo com a cidade, a sociedade e suas culturas, contribuindo para a compreensão do que seria uma arte pública. Segundo a Enciclopédia do Itaú Cultural, a partir dos anos 1970, a arte pública "visaria alterar a paisagem ordinária e, no caso das cidades, interferir na fisionomia urbana, recuperando espaços degradados e promovendo o debate cívico. 'O artista público é um cidadão em primeiro lugar', afirma o iraniano Siah Armajani”. A aplicação do conceito de arte pública às artes cênicas se expande quando o espectador passa a ser visto como coautor da experiência efêmera do teatro. Este conceito aqui
12. Espetáculo montado em 2015. Realizado somente por atores negros, saúda a rua num grande cortejo cênico, investigando e dialogando com e na periferia, tendo como argumento paralelo o debate sobre o genocídio da juventude negra da periferia. A partir da imagem do saco de lixo preto usado por legistas para cobrir cadáveres, nesse trabalho começamos a fazer perguntas sobre o que a sociedade vai julgando como lixo social e humano, o que ela vai relegando a um plano de ocultamento e obliteração, processo reflexo da sua urgente necessidade de esterilização da urbe. Perguntando-nos sobre que imagens da periferia vão sendo reiteradas a partir dessa prerrogativa, o trabalho tenta revelar o quê de oculto e dissensual que está por baixo desse saco preto. Marcados pelo ritmo dolente do Maracatu Cearense, a intervenção tomava as ruas numa ação que se fazia caminhando. Convocando o espectador a caminhar durante uma hora e meia pelo próprio bairro, fazíamos paradas que se estabeleciam como estações que discutiam, a partir da arquitetura e topografia vivenciada, o que essa ação produz de litígios no discurso do medo e violência que habita a cidade.

13.

Outro espetáculo do nosso repertório,

"Todo Camburão tem um Pouco de Navio Negreiro", narra a saga de um personagem negro que de oprimido passa a ser opressor. Ao assassinar um jovem na periferia, este personagem vai a tribunal e os espectadores, como júri popular, é quem decidem o futuro do nosso herói, na maioria das vezes levantando argumentos e tensionando os discursos apresentados.

14.

É Raymond Willians que, ligado aos ideais utópicos e marxistas, lança-nos essa diferença entre "cultura comum" e "cultura em comum", entendendo esta última como o processo de reapropriação hierarquizada dos valores criados por uma pequena camada da sociedade. A "cultura comum" "exige uma ética de responsabilidade comum, plena participação democrática em todos os níveis da vida social, incluindo a produção material e o acesso igualitário ao processo de criação da cultura" (EAGLETON, 2011, p. 169). O filósofo Terry Eagleton, defendendo essa concepção aponta que "a teoria de Willian (...) não pode ser rejeitada pelos pós modernos como nostalgia organicista, em parte porque envolve transformações políticas cujas implicações plenas são revolucionárias, e em parte porque vê a cultura não como um todo integrado, mas como 'um sistema muito complexo de desenvolvimentos especializados"” (EAGLETON, 2011, p. 172, grifo do autor). 
usado amplia a compreensão do acesso aos produtos de arte nos espaços públicos (em sua maioria monumentos), para repensarmos a forma como o espectador se relaciona com estes, tirando-o do espaço de contemplação para a configuração de uma experiência a ser vivida. Desse modo, pensar num "artista-cidadão" é ampliar sua postura frente às normas da sociedade, experiência emancipada capaz de suscitar um ato de transgressão constante às suas leituras e ações sobre a cidade. Nesse contexto, as artes cênicas muito têm contribuído para essa reflexão, seja nas suas intervenções urbanas ou mesmo nas performances e happenings realizados nos espaços públicos das cidades desde os anos de 1970. Pensar o teatro como um acontecimento público, uma cultura comum, significa não somente ampliar o seu alcance dentro do mundo contemporâneo, mas refazer e reinventar ativamente o próprio teatro. Antonin Artaud (2006, p. 8) já falava-nos que "romper a linguagem para tocar na vida é fazer ou refazer o teatro; e o importante é não acreditar que esse ato deva permanecer sagrado, isto é, reservado. O importante é crer que não é qualquer pessoa que pode fazê-lo, e que para isso é preciso uma preparação”. De que preparação nos fala Artaud? No campo da pesquisa aqui apresentada, ela age reiterando a separação entre artista e público ou relembra-nos da necessidade de, enquanto artistas, fortalecermos nosso universo referencial para pensar num teatro que se lança, em rigor, aos desafios aqui lançados?

Nessa acepção, mesmo discordando do conhecimento especializado, o Grupo Tá na Rua, trabalhando no Rio de Janeiro desde 1980, tem construído um consistente espaço laboratorial para o treinamento do ator de rua interessado nesse fluxo arte e vida. Da sala de ensaio às praças da Lapa e outros bairros cariocas, os atores vão, no dia-a-dia, reaprendendo sua relação com a cidade e seus habitantes, investindo numa poética do acaso e do improviso atrelada ao arsenal de jogos e vivências que os mesmos acumulam em laboratório. É essa perspectiva que pode nos levar a pensar que a noção de "preparação" defendida por Artaud possa ter a ver com esse processo de formação do cidadão para a catalisação do universo poético inscrito na cidade, reconhecendo no ator uma potência de agenciamento da leitura do mundo enquanto arte.

Amir Haddad ainda vai além ao apropriar-se da noção de arte pública reivindicando uma noção de arte enquanto direito civil onde, assim como o direito à saúde e à educação pública, o cidadão tenha acesso a uma arte pública, financiada com recurso público, como interesse geral da nação. O Nóis de Teatro, assim como Haddad, é partidário de que as artes públicas devam ser financiadas com recurso público, garantindo assim a subsistência 
de artistas que têm pautado a arte como produção de cidadania na sociedade contemporânea. O que se quer dizer com isso? Ao passo que a cidade se compreende como celeiro poético, o cidadão passa a se relacionar com a arte-ofício - aquela realizada de modo especializado pelos artistas que têm o teatro como profissão - de modo emancipado, momento em que ele pratica, conforme Haddad (2008, p. 225), um exercício de ludicidade "e assume um único papel - o de ser humano livre, criativo, fértil, transformador", caminhando para uma experiência aprofundada com o universo de códigos e símbolos inscritos nesse teatro que habita a cidade. Muito mais do que uma poética cidadã, reivindica-se aqui uma cidadania que se entenda e se faça poética.

Haddad (2008, p. 224), na busca da "construção de um outro mundo, dentro do qual a vida comunitária e a cidade estão incluídas", revela, dessa forma, um teatro que não só agencia um acontecimento participativo, mas com isto parece produzir, também, outras experiências de cidade. Haddad convoca o teatro ao propósito de fornecer ao ser humano "espaço para o seu sentimento gregário e comunitário, contribuindo assim para a construção de uma nova cidade e uma nova sociedade, onde as diferenças sociais e culturais poderão ser administradas e o sonho utópico da construção da 'cidade feliz' possa ser retomado" (HADDAD, 2008, p. 227, grifo do autor). Assumindo a sua condição performativa, seu teatro mais do que representar, produz cidade. E se não produz, apresenta-lhe choques, quebras, cesuras e fendas, abrindo a cidade a seus múltiplos habitantes enquanto possibilidade de uso, desestabilizando o que se tem como "mercado de arte", além de rever a própria noção normatizada e hegemônica de urbanismo.

Essas mobilizações, é importante ressaltar, não interferem somente no discurso político sobre a arte e sua possível função ética e social, mas fervilha diretamente no jogo cênico utilizado para alcançar tais anseios. No caso do trabalho realizado pelo Nóis de Teatro, em Fortaleza, as praças e ruas são vistas e utilizadas como lócus dessa tensão arte e vida. A partir das ruas, sobretudo as periféricas, têm surgido experimentos poéticos que tangenciam o acesso de uma população às artes públicas como direito político e civil e à linguagem que surge desse ensejo como sítio de invenção de possibilidades criativas. Esse entendimento é o que tem contribuído para tirar nosso trabalho daquele lugar "sacralizado" - que tem o poder de salvar uma comunidade -, para tocar nossos pés no chão e compreendermo-nos como artistas e cidadãos interessados em discutir a cidade e estabelecer o seu discurso poético junto a ela. Começamos a perceber que não há soluções mensuráveis para a cidade. As soluções 
são todas do agora, da emergência, elas não podem se fixar. Vejamos o que Amir Haddad nos fala sobre sua experiência:

\begin{abstract}
Então você não foi à rua para salvar os pobres? Para ensinar os ignorantes? Para levar cultura aos incultos? Pra dar lições de saúde? Higiene? Sexualidade? Política? Não! Fomos às ruas porque minhas descobertas sobre espaço e as relações do ator e do público no espaço aberto, seus limites e possibilidades me levaram a isso. Não havia em minha atitude nenhuma postura messiânica, evangelizadora-evangélica. Pelo Contrário! Não fui à rua para salvar ninguém, mas sim para salvar a mim mesmo da morte, da pasmaceira em que eu me via metido, em um teatro brasileiro envergonhado e acovardado, ou segregado (HADDAD, 2008, p. 145).
\end{abstract}

Nesse espaço de troca e relação, o contato com a poética de Amir Haddad e o Tá na Rua foi de grande importância para que pudéssemos entender um teatro que não busca "separar uma parte da cidade para celebrar o teatro ou pegar um pedaço da cidade e colocar dentro de um edifício para que ela esteja ali simbolizada, mas sim, pensar toda a cidade como uma possibilidade teatral" (HADDAD, 2008, p. 219), o que nos leva ao desejo militante e poético de um teatro que deixe "de ser produto cultural isolado num espaço, para se transformar em usufruto da cidade toda" (HADDAD, 2008, p. 223).

É exatamente esse tipo de pulsão, como no trabalho realizado por Amir Haddad e seus atores, que coloca o teatro e a rua como acontecimentos paralelos, borrando as fronteiras entre arte e vida e fortalecendo o pilar da ponte que as interliga: o caráter estético do mundo enquanto museu, enquanto obra passível de ser transformada ativamente pela experiência poética e pública.

Preparando a saída para as ruas: a busca de um novo abrigo

Nesse breve percurso traçado, podemos adentrar uma das dobras na percepção do Nóis de Teatro sobre o teatro de rua e suas possibilidades, sobretudo pela necessidade de discutir a cidade. Em nossas práticas vividas desde a fundação do grupo, em 2002, a tradição popular sempre atravessou nossas experiências, sejam os folguedos e brinquedos rurais ou mesmo a representação folclorista dessas manifestações como espaço idealizado. Todavia, foi o processo de montagem do espetáculo "Sertão.doc" (Figura 12), em 2010 que, justamente ao tratar de questões do campo, convocou-nos a discutir nosso lugar enquanto habitantes da cidade. Foi nesse processo que começamos a adentrar em outras linguagens e formas de pensar teatro de rua, sobretudo por termos refletido 
sobre nossa ação cultural enquanto artistas da cidade que estavam encenando um espetáculo sobre questões do campo. O processo de autocrítica e implicação de um olhar estrangeiro sobre as realidades campesinas foi o disparo para que a encenação buscasse referenciais urbanos e cosmopolitas para tratar dos dados que encontramos na pesquisa para a montagem ${ }^{15}$. Daí que, ao começar a tensionar nosso discurso enquanto artistas que militam e fazem teatro na periferia da cidade, nossa experiência teatral passa a ser atravessada por nossa relação com o bairro, realidade que nos impele a mobilização de outros discursos sobre a cidade contemporânea. Começamos a pensar num teatro que quer discutir cidade.

Jogando com essa ideia, o trabalho do Nóis de Teatro passa a incorporar o desejo de discussão sobre os entraves políticos entre centro e periferia, trazendo para a cena elementos vistos cotidianamente nas ruas como material que compõe cena e dramaturgia. Assim, entendendo a teatralidade própria da rua, em 2011, montamos, junto ao Grupo Pavilhão da Magnólia, o espetáculo "Assunção 285 - A tragédia anunciada de um forte que virou cidade"16. Partindo no ônibus "Assunção 285", o público era convidado a viajar por diversos pontos da cidade, onde em cada parada uma cena se realizava, tal qual "O Jardim das Flores de Plástico". Saindo da calçada do Theatro José de Alencar, no centro histórico de Fortaleza, passávamos pela Beira-Mar, seguindo pela orla e revelando a imagem de uma avenida que de um lado possui um grande hotel que esbanja em luxo - o Marina Parque - e do outro uma comunidade periférica - o Oitão Preto - , até chegarmos à ponte do Rio Ceará, de onde podemos ver o encontro do rio com o mar. Atravessávamos o rio numa balsa para, na outra margem, realizar cenas ritualizadas sobre o nascimento da cidade e, no retorno, visitarmos viadutos, avenidas e praças tentando perceber suas vozes ecoantes, dado seus altos valores monumentais na configuração da história da cidade.

Com uma direção cênica dividida por mim e Nelson Albuquerque, a poética do espetáculo era constituída a partir dos espaços da cidade, vivenciados em quatro horas de percurso. As cenas aconteciam dentro do ônibus, fora ou em cima dele, e até mesmo em percursos de veículos que o seguiam em paralelo. Uma experiência de fluxo sobre os lugares da cidade que atravessa-se como aprendizado inigualável na história do Nóis de Teatro. Contudo, o que se aponta desde aqui, a partir dessa memória, é o caráter de mobilização de uma experiência de cidade junto ao espectador, levando-o a uma vivência poética que lhe dispense de um cotidiano embrutecido que mal percebe as arquiteturas e topografias materiais e discursivas
15.

O espetáculo buscava fazer uma reflexão sobre a situação do homem do campo, sobretudo em virtude de uma ampla pesquisa que vinha se delineando sobre o agronegócio enquanto estratégia de controle sobre a produção agrícola rural.

16.

Tendo, infelizmente, realizado uma única apresentação, dado o alto custo para sua realização, a montagem foi resultado do projeto de intercâmbio entre grupos teatrais realizado pela Secretaria de Cultura de Fortaleza / SECULTFOR. 
de uma Fortaleza cada vez mais entupida de carros. Ao montar um novo espetáculo em percurso, o Nóis de Teatro incorpora a experiência de "Assunção 285" como memória propulsora de outros desafios, tirando o espectador do ônibus para vivenciar a cidade a partir dos pés, da caminhada pelo bairro.

Esse aparato de histórias foram renovando nossas experiências enquanto artistas urbanos, revelando-nos os conflitos que o urbanismo provocou na construção das cidades contemporâneas. Nesse sentido, Carreira e Matos (2016, p. 27) falam-nos que

trabalhar com a noção de cidade, ou seja, de um teatro na cidade, não implica em desconhecer a tradicional ideia de teatro de rua, mas sim ampliar esse conceito tornando-o mais complexo, buscando pensar a teatralidade que dialoga com a cidade como dramaturgia. Por isso, parece oportuno expandir a ideia de rua, considerando os fluxos que delimitam e definem nossas cidades.

Revela-se, assim sendo, para o grupo, um teatro que se problematiza na busca por complexificar também o olhar sobre a cidade, processo que não significa, no entanto, um recalcamento da nossa raiz tradicional do teatro de rua, pelo contrário, a partir do que se delineia aqui é possível perceber, como aponta Carreira, um processo, inclusive, de complexificação também dessa experiência. Foi a partir dessas vivências que o conceito de teatro de rua começou a se expandir para o Nóis de Teatro. Para além das especialidades do trabalho de ator e de encenação, existe um universo plural entre as noções de arte e vida que pode pulsar enquanto diferença na construção da imagem da cidade, produzindo um teatro que performa outras realidades e cria outros mundos e se não os cria, tensiona o estado normatizado das coisas. Este lugar consciente de ação nos tem feito pensar num teatro de rua que está interessado não somente em discutir a cidade, entendendo-a como dramaturgia, mas as próprias instabilidades que o "empilhamento dos tempos" tem gerado na nossa compreensão sobre a mesma. Em sequência, faz-se necessário concordar com Agamben (2009, p. 69) quando ele nos fala que "somente quem percebe no mais moderno e recente índices e assinaturas do arcaico pode dele ser contemporâneo". Agamben vai além e fala-nos que contemporâneo é também aquele que

dividindo e interpolando o tempo, está à altura de transformá-lo e de colocá-lo em relação com outros tempos, de nele ler de modo inédito a história, de "citá-la" segundo uma necessidade que não provém de maneira nenhuma do seu arbítrio, mas de uma exigência à qual ele não pode [não ${ }^{17}$ ] responder (AGAMBEN, 2009, p. 72, grifo do autor).
17.

Há um pequeno erro na tradução de Agamben realizada pela Editora Argos, usada como referência na dissertação. Com o texto em italiano, podemos perceber que, diferentemente da versão em português, o autor fala de uma exigência à qual ele "não pode" não responder": "dividendo e interpolando il tempo, è in grado di trasformarlo e di metterlo in relazione con gli altri tempi, di leggerne in modo inedito la storia, di "citarla" secondo una necessità che non proviene in alcun modo dal suo arbitrio, ma da un'esigenza a cui egli non può non rispondere" (AGAMBEN, 2008, p. 24). 
A partir desses paradigmas, configura-se um desejo vertiginoso de buscar não mais apenas representar uma cidade possível, mas de viver um teatro que, na sua força performativa, ponha em xeque e em movimento todo plano fixado e totalizado de cidade, gerando, a partir de sua própria força cênica, outros modos de habitar e conviver nela.

Os artistas que abandonaram o espaço especializado, para retomar um desejo de se engajar na busca de outro abrigo, querendo ou não, a recusa de um e o desejo do outro faz certo sentido. Antoine Vitez argumenta que com esse movimento, "se quer alcançar a realidade, porque a imagem e a suspeita em relação ao antigo teatro deixam de fazer sombra em benefício de um clima, de um ambiente" (CARDOSO, 2008, p. 224).

Para esses artistas, a sala preta do teatro convencional já não se configura mais como um espaço tão neutro assim, carregando na sua materialidade, como dito outrora, uma série de elementos que a distanciam de uma parcela da cidade e que, de certo modo, também limita o campo de ação poética de um artista interessado no caos multiforme da vida urbana. O pesquisador Ricardo Brugger Cardoso ainda complementa esse pensamento ao dizer-nos que

na experiência teatral moderna, o ator se tornou o centro das discussões. Atuar ou representar passou a ser uma função compreendida como um objeto altamente complexo apresentado para o público, desviando para si a atenção geral em relação ao resto da estrutura de um determinado evento. Contudo, algumas análises mais recentes apontam para o fato que os espaços cênicos fechados nunca atuaram como filtros ou molduras totalmente neutros, pois sempre apresentaram códigos que interferem direta ou indiretamente na compreensão do próprio espetáculo (CARDOSO, 2008, p. 61).

O que interessa dizer é que esse teatro que se faz no espaço público pelo Nóis de Teatro, o Tá na Rua, o Pavilhão da Magnólia, e uma série de outros artistas contemporâneos ${ }^{18}$, para além da falsa neutralidade da caixa cênica forjada como espelho do mundo, produz um enfrentamento à lógica normatizada da cidade, entrando diretamente no mundo enquanto museu e, percebendo-o como 'a obra', apresenta-lhe fissuras nas suas diversas temporalidades, nos becos e vielas esquecidos da sua própria história.
18

A cena teatral de rua contemporânea tem investido assertivamente em processos criativos que engajam o caminhar como prática estética, seja no corpo do elenco ou no que provoca ao espectador. Em São Paulo, alguns grupos tem se dedicado ao referencial poético dos bairros onde atuam, investindo em criações site-specific. Espetáculos como "Barafonda", da Cia São Jorge de Variedades ou "Bom Retiro 938 metros", do Teatro da Vertigem, propõem experiências que se inscrevem como imersão nos bairros da grande metrópole, tais como Barra Funda e Bom Retiro. Já a Cia Trupé de Teatro, tendo como start criativo a noção de "deriva", propõe um espetáculo itinerante, com três horas de duração onde, a partir do cenário vivo composto por ruas e praças da região do Baixo Centro da cidade de Sorocaba, encena a peça "Um dia o raio caiu, e o baixo ventre da cidade se abriu”. Em Fortaleza, o Grupo Teatro de Caretas tem se dedicado em um conciso processo de pesquisa sobre as ruas da cidade, convocando os espectadores a caminhar com seu espetáculo "Final de Tarde", dirigido pelo mineiro André Carreira. 


\section{REFERENNCIAS}

AGAMBEN, Giorgio. O que é o contemporâneo? e outros ensaios. Chapecó: Argos, 2009.

AGAMBEN, Giorgio. Che cos'è il contemporâneo. Nottetempo: Roma, 2008.

ARTAUD, Antonin. O teatro e seu duplo. São Paulo: Martins Fontes, 2006.

BAUDELAIRE, Charles. Edgar Allan Poe: Sua vida e sua obra. In: Poesia e Prosa. Rio de Janeiro: Nova Aguilar, 1995.

BAUDELAIRE, Charles. O pintor da vida moderna. São Paulo: Bira Câmara Editor, 2010

BENJAMIN, Walter. Paris, capital do século XIX. In: Espaço e Debates Revista de Estudos Regionais e Urbanos No 11, 1984.

BENJAMIN, Walter. Charles Baudelaire: um lírico no auge do capitalismo. São Paulo: Brasiliense, 2000.

BERMAN, Marshall. Tudo o que é sólido desmancha no ar: a aventura da modernidade. São Paulo: Cia das Letras, 1986

CARDOSO, Ricardo José Brugger. A cidade como palco: o centro do Rio de Janeiro como lócus da experiência teatral contemporânea. Rio de Janeiro: Secretaria Municipal das Culturas, Coordenadoria de Documentação e Informação Cultural; Gerência de Informação, 2008. CARREIRA, André. Dramaturgia do espaço urbano e teatro de invasão. In: Reflexões sobre a cena. MALUF, Sheila Diab \& AQUINO, Ricardo Big de (orgs). Maceió: EDUFAL, Salvador; EDUFBA, 2005. CARREIRA, André; MATOS, Lara. Transitando pelas ruas: uma cena que constrói cidades. In: TURLE, Licko; TRINDADE, Jussara e GOMES, Vanéssia (orgs). Teatro de rua: discursos, pensamentos e memórias em rede. Fortaleza: Aldeia Casa Viva, 2016.

CERTEAU, Michel de. A Invenção do Cotidiano. Volume 1: Artes de Fazer. Petrópolis, RJ: Vozes, 2014.

DELEUZE, Gilles. A imanência: uma vida... Educação \& realidade, Porto Alegre, v. 27, n. 2, jul.-dez. 2002

EAGLETON, Terry. A ideia de cultura. São Paulo: Editora Unesp, 2011 FÉRAL, Josette. Por uma Poética da Performatividade: o teatro performativo. Sala Preta, São Paulo, n. 8, 2008, p. 197-210.

GUATTARI, Felix; ROLNIK, Suely. Micropolítica: cartografias do desejo. 2. ed. Petrópolis: Vozes, 1986.

HADDAD, Amir. In: TURLE, Licko; TRINDADE, Jussara (orgs). Tá na rua: teatro sem arquitetura, dramaturgia sem literatura, ator sem papel. Rio de Janeiro (RJ): Instituto Tá Na Rua para as Artes, Educação e Cidadania, 2008.

LATOUR, Bruno. Jamais fomos modernos: ensaio de antropologia simétrica. São Paulo: Editora 34, 2013. 
OITICICA, Hélio. Aspiro ao Grande Labirinto. Rio de Janeiro: Rocco, 1986

OITICICA, Hélio. O Museu é o Mundo: Hélio Oiticica. Rio de Janeiro: Beco do Azougue, 2011

RANCIÈRE, Jacques. O mestre ignorante: cinco lições sobre emancipação intelectual. Belo Horizonte: Autêntica, 2002

ROCHA, Enrico. O mundo é a obra. In: Jornal O Povo, de 01 de maio de 2014. Disponível em: www.opovo.com.br/app/opovo/ vidaearte/2014/05/01/ noticiasjornalvidaearte,3244017/o-mundo-e-a-obra.shtml. Acesso em: 28/06/2015

ROCHA, Enrico. Nem marginal nem herói. In: Jornal Diário do Nordeste, de 01 de maio de 2014. Disponível em: http://diariodonordeste.verdesmares.com.br/cadernos/caderno-3/nem-marginal-nem-heroi-1.1006639. Acesso em: 28/06/2015

ROLNIK, Suely. Cartografia sentimental: transformações contemporâneas do desejo. Porto Alegre: Sulina: Editora da UFRGS, 2014 